\title{
Signaling pathways in cerebral vasospasm
}

\author{
Flávio Ramalho Romero', Eberval Gadelha Figueiredo², Manoel Jacobsen Teixeira²
}

São Paulo University, São Paulo, SP, Brazil.

\begin{abstract}
Cerebral vasospasm is a deadly complication following the rupture of intracranial aneurysms. One new development in the experimental treatment of cerebral vasospasm is the looming target of signaling pathways. The pathogenesis of cerebral vasospasm involves multiple signaling pathways in proliferation, inflammation, cell death, smooth muscle phenotype changes, vascular remodeling, and contraction. A review of all of these areas is beyond the scope of this article, and as such, three systems that mediate these vascular responses have been selected: the tyrosine kinase-MAP kinase pathway, the sphingosine-1-Rho myosin light chain kinase pathway and protein kinase $C$.
\end{abstract}

\section{KEYWORDS}

Cerebral vasospasm, signaling pathways, protein kinase $C$.

\section{RESUMO}

Vias sinalizadoras em vasoespasmo cerebral

O vasoespasmo cerebral é a complicação mais grave após a ruptura de um aneurisma intracraniano. Um novo foco experimental de tratamento de vasoespasmo cerebral são as vias sinalizadoras. A patogênese do vasoespasmo cerebral envolve múltiplas vias de sinalização na proliferação, inflamação, morte celular, alterações fenotípicas da muscultura lisa, remodelamento vascular e contração. Uma revisão de todas essas áreas é o objetivo deste artigo, e três sistemas que comandam essa resposta vascular foram selecionados: a via da tirosina quinase-MAP quinase, a via esfingosina1-Rho miosina quinase e a proteína quinase $C$.

\section{PALAVRAS-CHAVE}

Vasoespasmo cerebral, vias de sinalização, proteína quinase $C$.

\section{Introduction}

Cerebral vasospasm is a deadly complication following the rupture of intracranial aneurysms. ${ }^{4,19,23,28}$ The time course of cerebral vasospasm is unique in that it is slow developing, usually takes 4-7 days to peak, but lasts up to 2-3 weeks, and is resistant to most known vasodilators. ${ }^{4,23,27}$ These special features make cerebral vasospasm the most important determinant in the outcome of patients suffering subarachnoid hemorrhage. Vasospasm adversely affects $10 \%$ to $20 \%$ of patients with aneurysmal SAH. ${ }^{4,5,7,11,15,19}$ Although it is present on catheter angiograms in $40 \%$ to $70 \%$ of patients with $\mathrm{SAH}$, only $20 \%$ to $30 \%$ will develop clinical vasospasm. ${ }^{11,15,27,28}$ Up to $15 \%$ of patients surviving the ictus of SAH experience stroke or death from vasospasm despite maximal medical therapy, including hemodynamic therapy and nimodipine. $4,7,27,28$

The available treatment strategies include mechanical dilation of spastic cerebral arteries (angioplasty) and non-selective vasodilatation such as by $\mathrm{Ca}^{2+}$ channel blockers. ${ }^{4,7,9,15,27,28}$ One new development in the experimental treatment of cerebral vasospasm is the looming target of signaling pathways. Understanding vasospastic signals in cerebral arteries might offer a new avenue for selective treatment of cerebral vasospasm in the future.

The pathogenesis of cerebral vasospasm involves multiple signaling pathways in proliferation, inflammation, cell death, smooth muscle phenotype changes, vascular remodeling, and contraction..$^{20,22,24} \mathrm{~A}$ review of all of these areas is beyond the scope of this article, and as such, two systems that mediate these vascular

1. Neurosurgery Division of São Paulo University, São Paulo, SP, Brazil.

2. Neurosurgery Division of Hospital das Clínicas of Medical School of São Paulo University, São Paulo, SP, Brazil. 
responses have been selected: the tyrosine kinase-MAP kinase pathway and the sphingosine-1-Rho myosin light chain kinase pathway. Papers related to endothelin, nitric oxide, free radicals and gene therapy are not included in this review.

\section{Tyrosine kinase and mitogen- actived protein (MAP) kinase}

MAP kinase has been suggested to be one of the most important signaling pathways involved in cerebral vasospasm based in part on the role of MAP kinase in cell differentiation, proliferation, contraction, death and remodeling. ${ }^{1}$

MAP kinase is involved in the regulation of $\mathrm{CA}^{2+}$ in cerebral smooth muscle cells and in the contraction of cerebral arteries. ${ }^{1,2,10}$ Blood clot components including hemoglobin and vasoactive agents released from the vessel wall such as endothelin-1 enhance MAP kinase expression and activity in cerebral arteries. Free radicals activate MAP kinase in vascular smooth muscle cells. MAP kinase inhibitors were reported to decrease MAP kinase expression in vasospastic arteries and to reduce the degree of cerebral vasospasm in animal models. ${ }^{1}$ A recent study ${ }^{1}$ demonstrated that antisense oligodeoxunucleotides to MAP kinase abolished MAP kinase activity and phosporylated MAP kinase and reduce vasospasm in a rat model of subarachnoid hemorrhage. ${ }^{1,10}$

Because MAP kinase is a substrate of tyrosine kinase, the possible role of tyrosine kinase as an upstream modulator of MAP kinase in cerebral vasospasm needs to be addressed. ${ }^{6}$ Tyrosine kinase regulates intracellular $\mathrm{Ca}^{2+}$ and smooth muscle contraction induced by spasmogens including blood clot components and vasoactive agents. ${ }^{1,6,24}$ Tyrosine kinase is involved in the compaction of fibroblasts. Some G-protein coupled receptor agonist and growth factors activate tyrosine kinase. The level of these G-protein receptor agonist such as adenosine triphosphate and endothelins, growth factors, and their receptors are increased in cerebrospinal fluid or in cerebral arteries. ${ }^{1}$ Tyrosine activation phosphorylates other substrates such as Ras protein and phosphatidyl inositol-3 kinase tyrosine kinase. Ras is increased after spasmogen stimulation, and phospatidyl-inositol-3 kinase is enhanced after vasospasm in animals. The tyrosine kinase inhibitors sumarin but not phosphatidylinositol-3-kinase inhibitors reduced vasospasm in animal models. ${ }^{1,16-18,24}$

Overall, MAP kinase and particularly the extracelular regulated kinase (ERK) system is involved in proliferation, differentiation, and contraction of cerebral arteries after subarachnoid hemorrhage.

\section{Sphingosine-1 and Rho/ myosin light chain kinase}

Sphingosine-1-phosphate (S1P) is a bioactive sphingolipid metabolite that is known to mediate diverse cellular responses including cell growth, survival, and migration. ${ }^{2,24}$ Most of these effects have been attributed to its binding to a specific subfamily of $G$ protein-coupled receptors (GPCR), namely S1P. Recent studies have suggested that $\mathrm{S} 1 \mathrm{P}$ also plays a prominent role in the contraction of various types of smooth muscle. This review provides a brief overview of its role in this process and also highlights how S1P-dependent signaling serves as an important regulator of smooth muscle contraction. ${ }^{2,24}$

Sphingosine 1-phosphate (S1P) is stored in platelets and released on their activation. Similar to MAP kinase, many stimuli such as growth factors, cytokines, G-protein coupled receptors coupled receptor agonist, and antigens have been shown to increase sphingosine kinase activity and SP1 formation in different cell types, including smooth muscle cells. Indeed, SP1 has been implicated in the regulation of several important cellular processes, such as proliferation, differentiation, apoptosis and migration in these cells. ${ }^{2,24}$

Sphingosylphosphorylcholine (SPC), a sphingolipid, is a novel messenger for Rho kinase-mediated $\mathrm{Ca}^{2+}$ sensitization in the bovine cerebral artery but not for protein kinase $\mathrm{C}$. Rho and Rho kinase are believed to play roles in smooth muscle contraction and cytoskeleton reorganization. Rho kinase, wich is activated by the small guanosine triphosphatase. Rho, phosphorylates not only myosin light chain but also myosin phosphatase at its myosin binding subunit, thus inactivating myosin phosphatase. $^{2,24}$

\section{Protein kinase $\mathbf{C}$}

Twenty-five years after the discovery of protein kinase $\mathrm{C}$ (PKC), the physiologic function of $\mathrm{PKC}$, and especially its role in pathologic conditions, remains a subject of great interest. In the cerebral circulation, PKC plays a role in the regulation of myogenic tone by sensitization of myofilaments to calcium. Protein kinase $C$ phosphorylates various ion channels including augmenting voltage-dependent $\mathrm{Ca}^{2+}$ channels and inhibiting $\mathrm{K}+$ channels, which both lead to vessel contraction. These actions of PKC amplify vascular reactivity to different agonists and may be critical in the regulation of cerebral artery tone during vasospasm. ${ }^{8,18,24}$

Evidence accumulated during at least the last decade suggests that activation of PKC in cerebral vasospasm 
results in a delayed but prolonged contraction of major arteries after subarachnoid hemorrhage. Most of the experimental results in vitro or in animal models support the view that $\mathrm{PKC}$ is involved in cerebral vasospasm. Implication of PKC in cerebral vasospasm helps explain increased arterial narrowing at the signal transduction level and alters current perceptions that the pathophysiology is caused by a combination of multiple receptor activation, hemoglobin toxicity, and damaged neurogenic control. ${ }^{8,18,21,24,25}$

Activation of protein kinase $\mathrm{C}$ also interacts with other signaling pathways such as myosin light chain kinase, nitric oxide, intracellular $\mathrm{Ca}^{2+}$, protein tyrosine kinase, and its substrates such as mitogen-activated protein kinase. Even though identifying PKC revolutionized the understanding of cerebral vasospasm, clinical advances are hampered by the lack of clinical trials using selective PKC inhibitors. ${ }^{2,7,10,13,18}$

PKC may be involved in the initial contraction but not late stages contraction (vasospasm) in animal models. Degradation of the thin filament associated protein calponin in spastic arteries in an animal model has been reported. HA1077, an inhibitor of protein kinases, including Rho kinase and myosin light chain kinase, reduted vasospasm and calponin degradation in this model..$^{2,18,24}$

\section{Others signaling pathways}

Other signaling pathways that may be involved in the vasospasm include those activated by or involved in the contraction of cerebral arteries related to endothelin, ${ }^{3,8}$ nitric oxide synthase, ${ }^{13,17,26}$ bilirubin, ${ }^{14}$ matrix metalloproteinases, ${ }^{3,8,14}$ adhesion molecules, ${ }^{8}$ protein C, ${ }^{8,14,25}$ cyclic adenosine monophosphate/phosphodiesterase ${ }^{12,8}$ cyclic guanosine monophosphate, ${ }^{8}$ parathyroid hormone, ${ }^{8}$ erythropoietin and nicotinamide adenine dinucleotide phosphate oxidase. ${ }^{8}$

\section{Conclusion}

The pathogenesis of cerebral vasospasm involves multiple signaling pathways in proliferation, inflammation, cell death, smooth muscle phenotype changes, vascular remodeling, and contraction. Understanding vasospastic signals in cerebral arteries might offer a new avenue for selective treatment of cerebral vasospasm in the future. Additional research is required to clarify the roles of these pathways and agents in vasospasm.

\section{References}

1. Adam LP, Hathaway DR. Identification of mitogen-activated protein kinase phosphorylation sequences in mammalian h-caldesmon. FEBS Lett. 1993;322(1):56-60.

2. Bulter WE, Peterson JW, Zervas NT, Morgan KG. Intracellular calcium, myosin light chain phosphorylation, and contractile force in experimental cerebral vasospasm. Neurosurgery. 199;38(4):781-7.

3. Cook DA, Vollrath B. Free radicals and intracellular events associated with cerebrovascular spasm. Cardiovasc Res. 1995;30(4):493-500.

4. Dankbaar JW, Rijsdijk M, Van der Schaaf IC, Velthuis BK, Wermer MJ, Rinkel GJ. Relationship between vasospasm, cerebral perfusion, and delayed cerebral ischemia after aneurysmal subarachnoid hemorrhage. Neuroradiology. 2009;51(12):813-9.

5. Dehdashti AR, Mermillod B, Rufenacht DA, Reverdin A, De Tribolet N. Does treatment modality of intracranial ruptured aneurysms influence the incidence of cerebral vasospasm and clinical outcome? Cerebrovasc Dis. 2004;17(1):53-60.

6. Di Salvo J, Steusloff A, Semenchuk L, Satoh S, Kolquist $\mathrm{K}$, Pfitzer G. Tyrosine kinase inhibitors suppress agonistinduced contraction in smooth muscle. Biochem Biophys Res Commun. 1993:15;190(3):968-74.

7. Dorsch NW. Cerebral arterial spasm - a clinical review. $\mathrm{Br}$ J Neurosurg. 1995;9(3):403-12.

8. Dumont AS, Dumont RJ, Chow MM, Lin CL, Calisaneller T, Ley KF, et al. Cerebral vasospasm after subarachnoid hemorrhage: putative role of inflammation. Neurosurgery. 2003;53(1):123-33.

9. Fassbender K, Hodapp B, Rossol S, Bertsch T, Schmeck $\mathrm{J}$, Schütt $\mathrm{S}$, et al. Inflammatory cytokines in subarachnoid haemorrhage: association with abnormal blood flow velocities in basal cerebral arteries. J Neurol Neurosurg Psychiatry. 2001;70(4):534-7.

10. Feigin VL, Rinkel GJ, Algra A, Vermeulen M, Van Gijn J. Calcium antagonists in patients with aneurysmal subarachnoid hemorrhage: a systematic review. Neurology. 1998;50(4):876-83.

11. Frontera JA, Fernandez A, Schmidt JM, Claassen J, Wartenberg KE, Badjatia N, et al. Defining vasospasm after subarachnoid hemorrhage: what is the most clinically relevant definition? Stroke. 2009;40(6):1963-8.

12. Hijdra A, Van Gijn J, Nagelkerke NJ, Vermeulen M, Van Crevel $\mathrm{H}$. Prediction of delayed cerebral ischemia, rebleeding, and outcome after aneurysmal subarachnoid hemorrhage. Stroke. 1988;19(10):1250-6.

13. Hino A, Tokuyama Y, Weir B, Takeda J, Yano H, Bell Gl, et al Changes in endothelial nitric oxide synthase mRNA during vasospasm after subarachnoid hemorrhage in monkeys. Neurosurgery. 1996;39(3):562-7.

14. Horowitz A, Menice CB, Laporte R, Morgan KG. Mechanisms of smooth muscle contraction. Physiol Rev. 1996;76(4):9671003.

15. Keyrouz SG, Diringer MN. Clinical review: prevention and therapy of vasospasm in subarachnoid hemorrhage. Crit Care. 2007;11(4):220.

16. Khurana VG, Besser M. Pathophysiological basis of cerebral vasospasm following aneurysmal subarachnoid haemorrhage. J Clin Neurosci. 1997;4(2):122-31.

17. Khurana VG, Sohni YR, Mangrum WI, McClelland RL, O'Kane DJ, Meyer FB, et al. Endothelial nitric oxide synthase gene polymorphisms predict susceptibility to aneurysmal subarachnoid hemorrhage and cerebral vasospasm. J Cereb Blood Flow Metab. 2004;24(3):291-7. 
18. Laher I, Zhang JH. Protein kinase $C$ and cerebral vasospasm. J Cereb Blood Flow Metab. 2001;21(8):887-906.

19. Lysakowski $C$, Walder B, Costanza MC, Tramèr MR. Transcranial Doppler versus angiography in patients with vasospasm due to a ruptured cerebral aneurysm: a systematic review. Stroke. 2001;32(10):2292-8.

20. Macdonald RL. Pathophysiology and molecular genetics of vasospasm. Acta Neurochir Suppl. 2001;77:7-11.

21. Macdonald RL, Kassell NF, Mayer S, Ruefenacht D, Schmiedek P, Weidauer S, et al. CONSCIOUS-1 Investigators. Clazosentan to overcome neurological ischemia and infarction occurring after subarachnoid hemorrhage (CONSCIOUS-1): randomized, double-blind, placebo-controlled phase 2 dosefinding trial. Stroke. 2008;39(11):3015-21.

22. Macdonald RL, Weir BK. A review of hemoglobin and the pathogenesis of cerebral vasospasm. Stroke. 199;22(8):971-82.

23. Neil-Dwyer G, Lang DA, Doshi B, Gerber CJ, Smith PW. Delayed cerebral ischaemia: the pathological substrate. Acta Neurochir (Wien). 1994;131(1-2):137-45.

24. Nishizawa S, Laher I. Signaling mechanisms in cerebral vasospasm. Trend Cardiovasc Med. 2005;15(1):24-34.
25. Ohkuma H, Suzuki S, Kimura M, Sobata E. Role of platelet function in symptomatic cerebral vasospasm following aneurysmal subarachnoid hemorrhage. Stroke. 199;22(7):854-9.

26. Pluta RM. Delayed cerebral vasospasm and nitric oxide: review, new hypothesis, and proposed treatment. Pharmacol Ther. 2005;105(1):23-56.

27. Roos YB, Levi M, Carroll TA, Beenen LF, Vermeulen M. Nimodipine increases fibrinolytic activity in patients with aneurysmal subarachnoid hemorrhage. Stroke. 2001;32(8):1860-2.

28. Weir B, MacDonald L. Cerebral vasospasm. Clin Neurosurg. 1993;40:40-55.

\section{Endereco para correspondência}

Flávio Ramalho Romero

Rua Pascoal Vita, 366, ap. 94, Vila Madalena

05445-000 - São Paulo, SP, Brasil

Telefones: (11) 3459-4416/(11) 9714-7720

E-mails: frromero@ig.com.br/romeroncr@gmail.com 